\title{
Integrating Online Assignments Checking in Introductory Courses
}

\author{
David Pundak \\ Web Learning Unit, \\ ORT Braude \\ Engineering College; \\ Engineering School \\ Kinneret College, Israel
}

dpundak@gmail.com

\author{
Miri Shacham \\ Teaching Dept., \\ ORT Braude \\ Engineering College, \\ Israel
}

\author{
Orit Herscovitz \\ Teaching \\ Technology and \\ Science Dept., \\ Technion Science \\ University, Israel
}

mshacham@netvison.net.il

orither@tx.technion.ac.il

\section{Executive Summary}

Web technology offers lecturers the option of checking students' assignments online. Several systems have evolved to deliver personal assignments to each student in a multi-participant course. These systems provide students with immediate feedback, allowing them to correct erroneous answers and referring them to relevant literary sources that can assist them with their assignments. These strategies influence the lecturers' teaching and their ability to respond to students' difficulties in real-time. The study examines student attitudes concerning the integration of the WebAssign (WA) Online Assignment Checker (OAC) in the teaching of academic courses. An on-line questionnaire investigated attitudes of 75 engineering students studying introductory academic courses assisted by OAC. The questionnaire included the following six dimensions: involvement and interest, understanding the studied material, lecturers' consideration of students' difficulties, importance of the course, tutorial methods and dishonest assignment submission. Significant findings emerged for attitudes in three dimensions. The students think that OAC assist lecturers to relate to their difficulties, contribute to their success in the course, and do not encourage cheating such as copying. No preference was found between submitting homework in hardcopy or online.

Keywords: Online assignment Checker - OAC, Student Attitudes, Understanding, Involvement, dishonest learner behavior.

\section{Introduction}

In recent years various strategies have developed to practice and evaluate students' learning material through online data bases including: online questions, tasks, learning classes, and up-to-date

Material published as part of this publication, either on-line or in print, is copyrighted by the Informing Science Institute. Permission to make digital or paper copy of part or all of these works for personal or classroom use is granted without fee provided that the copies are not made or distributed for profit or commercial advantage AND that copies 1) bear this notice in full and 2) give the full citation on the first page. It is permissible to abstract these works so long as credit is given. To copy in all other cases or to republish or to post on a server or to redistribute to lists requires specific permission and payment of a fee. Contact Publisher@InformingScience.org to request redistribution permission. reports of student achievements. This paper examines the use of an Online Assignment Checker (OAC) in web environment. The $\mathrm{OAC}$ allows academic or teaching staff to construct online assignments where each assignment is composed of series of questions dealing with issues studied in the course, or to present preparatory questions before the next lesson. The OAC allows students to cope with weekly assignments 
throughout the semester. On submission of the assignment, students receive immediate feedback for their responses through the OAC. In many cases the OAC allows additional opportunities to try again and correct mistaken responses (Bonham, Beichner, \& Deardorff, 2001; Brewer, 2009; Cuadros, Yaron, Leinhardt, 2007; Freasier, 2003; Liberatore, 2011; Pundak, Maharshak, \& Rozner, 2004).

The decision to integrate the OAC in introductory courses at the engineering college was based on the following aspects:

1. Improvement of assignment checking - providing a methodical weekly response to assignments for large groups of students.

2. Providing feedback to students - in the absence of orderly response, many students find it difficult to assess their status in relation to the course goals during the course. Using the OAC, students can follow their achievements throughout the course, and improve their performances.

3. Providing feedback to the lecturer - the system enables the lecturer to read the students' responses and grade each of the questions, to use statistical tools to assess each student's success and to obtain a comprehensive picture of the performances of the entire class. This information allows the lecturer to adapt the next lesson in consideration of the students' difficulties.

4. Improvement of student involvement - students' active participation in the performance of online assignments facilitates their greater involvement and responsibility throughout the learning process. This system complies with the "Just-in-Time teaching" approach (Mazur, 1997; Novak, Patterson, \& Gavrin, 2000), since the OAC allows the lecturer to provide continuous consideration of students' difficulties during the lesson (Redish, Steinberg, \& Saul, 1998).

\section{Integrating the OAC in Teaching}

There are various online assignment checkers: WA, LON-CAPA, Sapling Learning, MasteringChemistry, OWL - Online Web Learning, ALEKS and WileyPLUS. They can be classified into three main categories:

1. Tools in learning systems - these OACs are part of Leaning Management Systems (LMS). The LMS provide tools for the construction of online questions, the composition of questions for online assignments, management of grades, and reporting. For example, the Moodle environment facilitates the management of online assignments. The disadvantage is that the lecturer must construct the questions.

2. Open code systems - for example, LON-CAPA. The system is based on the use of an open code and can be downloaded and installed without fee. The responsibility for the integration of the system is imposed on the institution that uses it. These systems have sites that allow files of questions and assignments prepared by lecturers in other educational institutions to be downloaded. The lecturers who want to adopt the questions must check the appropriateness of the assignments for their own goals.

3. Commercial systems - such as ALEKS, OWL, WA, and WileyPLUS - allow questions to be mined from textbooks. After the lecturers have chosen an appropriate textbook, they can obtain the questions that appear in the online book approved by quality assurance. The advantage of these systems is that they offer a large variety of contents. The main disadvantage is the cost of the service.

The OAC system offers the lecturer new options that did not exist in traditional exercises, such as (a) random numbers- each student can be given similar questions, but the data that each one sees will be different, (b) immediate feedback - after the student answers, the system immediately re- 
sponds and indicates whether the answer is correct or incorrect, (c) if the answer was incorrect the student is given an opportunity to submit another answer. In many cases hints or reading texts from textbooks are provided, (d) planning the assignments - questions can be chosen from a very large reservoir, and the average time that it takes a student to answer a question is known in advance, (e) mixing questions - the computerized system allows different questions or a different order of questions to be given to each student.

\section{Lecturers' Attitudes Concerning OAC}

In traditional teaching where lecturers are required to check homework they usually use one of three methods: (1) giving homework without any checking, (2) random checking of a limited number of answers, or (3) employing teaching assistants to check homework (Bonham et al., 2001). In many cases no grade is given for the assignments or the grade given constitutes only a relatively small part in the final course grade. Research has indicated the following advantages for computerized systems for the checking of assignments:

1. A significant reduction in the time needed by the lecturer to prepare assignments, and relief from the burden of checking, collecting, and organizing grades (Freasier et al., 2003; Pundak et al., 2004).

2. The computerized system provides the lecturer with a broad collection of questions at different levels and different learning methods for each basic course.

3. The lecturer is able to construct a unique personal assignment for each student by random choice from a selection of questions.

Using this strategy, problems of automatic copying of solutions can be overcome. The lecturers' attitudes towards OAC oscillate between enthusiasm and a sense that learning processes and student achievements have improved immensely on the one hand (Harris, 2009; Liberatore, 2011) and reluctance to innovate with adherence to traditional teaching methods on the other hand (Pundak, Herscovitz, Shacham, \& Weizer-Biton). In recent years with the increasing use of LMS there is a decrease in lecturers' reticence to use computerized checking systems (Richards-Babb, Drelick, Henry, \& Robertson-Honecker, 2011).

\section{Students Attitudes toward OAC}

Most of the students today belong to a generation that has grown up in a Cyber environment and are used to functioning with it. For them, working on an OAC is activity in their natural learning environment. Students' attitudes towards learning with an OAC were described in several studies (Bonham et al., 2001; Liberatore, 2011; Pundak \& Rozner, 2004). In studies that compared students' attitudes towards OAC submission of assignments as opposed to non-computerized submission, it was found that most students enjoyed the use of computerized systems. The outstanding advantage of the computerized system, in the students' view, is that they can receive immediate feedback after presenting the answer. A further advantage is the opportunity provided by the system for re-submission when the first answer is incorrect. There are conflicting findings with regard to the potential contribution of the system to the students' achievements at the end of the course. Some studies found no significant difference in final exam results between those who had used different styles of submission. Contrastingly, other studies indicate a tight correlation between the time invested by students in learning the material for an introductory course and their achievements at the end of the course (Cuadros et al., 2007; Richards-Babb et al., 2011). The adoption of an OAC may increase the students' learning time, without the lecturer correspondingly increasing the time required for their follow-up after the assignments' preparation.

A study including 163 students in a general chemistry course (Liberatore, 2011) examined students' attitudes concerning the submission of homework in an online system. The research find- 
ings indicated that (a) the system enabled learning without punishment for mistakes, (b) hints, explanations, and instructions for solution were provided for difficult questions, (c) the detailed feedback for the students' incorrect answers enabled improvement of understanding, and (d) online questions enabled stage-by-stage learning, facilitating deeper understanding of the studied subjects.

\section{Problems of Integrity in Online and Regular Courses}

Many lecturers worry that online courses provide students with additional opportunities for inappropriate behavior including cheating. Studies that have investigated this issue produced conflicting results concerning the students' tendency to cheat when working on online systems in contrast to their behavior in regular courses. In a study by King, Guyette, and Pitrowski (2009) it was found that $73.8 \%$ of students who participated in the survey felt that it was easier to cheat in online courses. Contrarily, a study by Grijalva, Nowell, and Kerkvliet (2006) found no significant difference in the students' tendency to cheat between the online and regular assignments. Another study of 635 first degree and graduate students in several universities and colleges in the USA (Watson \& Sotille, 2010) surprisingly found that there was actually a higher percentage of dishonest events in traditional courses in comparison to online courses. This finding may be explained by social support/familiarity with friends in the class during collaborative work on assignments, which may remove moral obstacles against copying. This complex situation merits further investigation of students' attitudes concerning the tendency to cheat when using OAC.

\section{The Research Aim}

The research aim was to examine students' attitudes concerning the integration of an OAC in academic courses. The study examined students' attitudes regarding the following dimensions:

1. Understanding the material taught in the course

2. Involvement and interest in learning

3. The lecturers' consideration of students' learning difficulties

4. Traditional exercises versus online exercises

5. Lack of integrity (tendency to cheat)

6. Presenting homework through an OAC in comparison to hardcopy submission.

\section{Research Design}

\section{The Research Tool}

The research tool consisted of a specially designed questionnaire developed in our previous research (Pundak et al., 2004) to examine attitudes of students studying introductory courses assisted by an OAC. The questionnaire was adapted to meet the aim of the current research (see Appendix). The questionnaire was administered online. It included 28 statements sorted according to six dimensions shown in Table 1. The questionnaire was based on the 'Active Learning' approach and developed by Novak and Redish (Novak et al., 2000; Redish et al., 1998). 


\begin{tabular}{|c|l|l|l|l|}
\hline \multicolumn{5}{|c|}{ Table 1: Different dimensions of student attitudes concerning the integration of } \\
computerized checkers in basic courses
\end{tabular}

\section{The Research Population}

The on-line questionnaire was administered to 75 engineering students in an academic college in northern Israel who had studied for at least one semester with the assistance of the WA OAC (Table 2). The average number of courses in which they had used the WA before the research was 2.75 (S.D. 1.26). These students also studied in additional courses in which they used traditional handwritten or hardcopy submission of assignments.

\begin{tabular}{|c|l|c|l|}
\hline \multicolumn{5}{|c|}{ Table 2: The research population } \\
\hline GROUP NO. & \multicolumn{1}{|c|}{ COURSE } & N & \multicolumn{1}{c|}{ DEPARTMENT } \\
\hline 1. & Physical chemistry & 33 & Water engineering \\
\hline 2. & Electricity and Magnetism & 19 & $\begin{array}{l}\text { Water engineering and } \\
\text { software engineering }\end{array}$ \\
\hline 3. & Electricity and Magnetism & 14 & $\begin{array}{l}\text { Quality and reliability engi- } \\
\text { neering }\end{array}$ \\
\hline 4. & Modern Physics & 9 & Electrical engineering \\
\hline & Total & 75 & \\
\hline
\end{tabular}




\section{Research Method}

The OAC questionnaire allows us to identify students' attitudes in six dimensions, as described in the previous section. The validity of each item of the questionnaire was judged by five learning experts. The experts were asked to check that the questionnaire items reflected a positive attitude toward OAC. We excluded any item with less than $80 \%$ agreement between the experts. Following this process, 28 out of 35 items were found to be validated. The final version of the questionnaire contains 18 items expressing a positive approach toward $\mathrm{OAC}$ and 10 expressing a negative approach. Reliability of each dimension was tested with Cronbach's alpha. Three items $(1,15,19)$ were removed from the questionnaire to improve reliability. Zeros were used to signify that an item was irrelevant to the respondent. The zero values were considered as a missing value when calculating Cronbach's alpha or $\mathrm{t}$ tests.

To improve our categorization of the six domains we adopted a blend of two philosophies 'predeterminism' and 'row statistics', suggested by Adams et al. (2006). We exploited the advantage of the strengths of both approaches and avoided the weaknesses to obtain statistically robust categories that best characterize instruction thinking in the academic context for which this questionnaire was constructed. Guided by the research results, we then grouped the statements into new categories that were likely to be useful and were evaluated as statistically valid. These categories were not necessarily independent and not all statements needed to be ascribed to a category. This approach was justified because the different aspects of the students' attitudes were not necessarily independent; rather, an attempt was made to identify which portions of the data were useful to describe particular general aspects of the students' thinking. Relying on previous studies (Liberatore, 2011; Pundak \& Rozner, 2004; Richards-Babb et al., 2011) our null hypothesis was that the students, on average, would express a neutral position toward $\mathrm{OAC}$, or $\mathrm{H}_{0}=3.00$.

Content analysis (Shkedi, 2011) of responses to the open questions was conducted in three steps: 1. Mapping, 2. Categorizations 3. Mapping analysis. As a result of the content analysis five categories of data were identified: Submission through WA, Traditional submission, Submission with WA and in hardcopy, No preference, Not relevant/ no reply.

\section{Findings}

The reliability of the questionnaire was confirmed with Cronbach's alpha. The Cronbach's alpha of each dimension was calculated with SPSS; results appear in the right column of Table 3.

\begin{tabular}{|c|c|c|c|c|c|c|}
\hline \multicolumn{7}{|c|}{ Table 3: Results for the six dimensions $(\mathrm{N}=75)$} \\
\hline $\begin{array}{l}\text { DIMENSION } \\
\text { NO. }\end{array}$ & DIMENSION & MEAN & S.D. & $\begin{array}{l}t-\operatorname{tggt} \\
(\mathrm{df}=\mathbf{7 4})\end{array}$ & $\mathbf{P}$ & $\begin{array}{l}\text { CRON- } \\
\text { BACH'S } \\
\text { ALPHA }\end{array}$ \\
\hline 1 & $\begin{array}{l}\text { Involvement and } \\
\text { interest }\end{array}$ & 2.89 & 0.959 & -1.024 & 0.309 & 0.861 \\
\hline 2 & $\begin{array}{l}\text { Understanding the } \\
\text { studied material }\end{array}$ & 3.00 & 0.963 & 0.030 & 0.976 & 0.871 \\
\hline 3 & $\begin{array}{l}\text { Lecturers' consideration } \\
\text { of student difficulties }\end{array}$ & 3.41 & 0.752 & 4.683 & $0.000^{*}$ & 0.712 \\
\hline 4 & Success in the course & 3.27 & 0.818 & 5.060 & $0.000 *$ & 0.735 \\
\hline 5 & $\begin{array}{l}\text { Traditional in } \\
\text { comparison to online } \\
\text { exercises }\end{array}$ & 2.85 & 0.802 & -1.584 & 0.117 & 0.755 \\
\hline 6 & Lack of integrity & 3.47 & 0.917 & 5.350 & $0.000^{*}$ & 0.719 \\
\hline
\end{tabular}

* Significant finding 
Each of the questionnaire's six dimensions was tested with a one sample t-test to examine the mean difference between its mean and the value 3 . According to the null hypothesis the value 3.00 represents a neutral position regarding the various aspects of OAC. The null hypothesis is that there is no significance difference between the neutral position mean and mean of the study group in each dimension. The alternative hypothesis assumes there is a significant difference between the neutral position mean and the study group mean in each dimension. The results of the statistical t-test, with 74 degree of freedom (df), and the significance value (P) appear in Table 3.

The data in Table 3 indicate significant results for three dimensions of the students' attitudes: Dimension 3 - findings indicate that the students noticed that the course lecturers who received assignments through the WA are aware of the students' difficulties and relate to them. Dimension 4 - findings indicate that the students have a positive evaluation of the contribution of exercises assisted by the WA to their success in the course. Dimension 6 - findings indicate that the students tend to avoid copying or any cheating when submitting assignments through WA. Nonsignificant results indicate that responses for dimensions 1,2 and 5 were neutral.

At the end of the questionnaire the students were asked to respond to an open question dealing with their personal preference regarding assignments submission. The students were asked to choose between two options: online submission or traditional style submission. The students also pointed up an additional possibility of combined submission (both traditional and online), as practiced in some of the college courses.

Table 4 presents the categories that emerged from the students' responses to the open questions, their frequency and examples of the reasoning for the different categories. From Table 4 it can be seen that in general, students preferred to submit homework in hardcopy rather than through OAC. Including the component of combined submission with the online submission produced a balance regarding this issue since 39\% preferred to submit their assignment in hardcopy, and 37\% preferred to present assignments online or with mixed methods.

\begin{tabular}{|c|c|c|}
\hline \multicolumn{3}{|c|}{$\begin{array}{l}\text { Table 4: Analysis of students' responses concerning preferred method } \\
\text { of assignment submission }\end{array}$} \\
\hline $\begin{array}{l}\text { CATEGORY of } \\
\text { PREFERENCE }\end{array}$ & $\begin{array}{l}\text { FREQUENCY } \\
\quad(\mathbf{N}=\mathbf{7 5})\end{array}$ & EXAMPLE OF REASON GIVEN \\
\hline $\begin{array}{l}\text { Submission through } \\
\text { WA }\end{array}$ & $25 \%$ & $\begin{array}{l}\text { I love the WA method because I get an immediate indication } \\
\text { whether my solution is correct instead of waiting a week } \\
\text { I have a difficult attention and concentration disability and } \\
\text { high level hyperactivity. The system helps me with composi- } \\
\text { tion and writing answers }\end{array}$ \\
\hline Tradition submission & $39 \%$ & $\begin{array}{l}\text { I would prefer to present homework in hardcopy. Then I re- } \\
\text { ceive consideration of the manner and strategy of solution } \\
\text { and not just regarding the final solution as on WA } \\
\text { I prefer to present exercises in hardcopy, its more comfort- } \\
\text { able, takes less time and allows me to use a better learning } \\
\text { method. There's not always so much time to sit facing the } \\
\text { computer, especially when it gets stuck or doesn't work. }\end{array}$ \\
\hline $\begin{array}{l}\text { Submission with WA } \\
\text { and also in hardcopy. }\end{array}$ & $12 \%$ & $\begin{array}{l}\text { The combination of both methods is quite O.K. - it provides } \\
\text { an opportunity to work alone and yet also provides feedback } \\
\text { from the teaching assistant's check. }\end{array}$ \\
\hline No preference & $11 \%$ & $\begin{array}{l}\text { It's no different, in both methods I have to go through the } \\
\text { whole process to find the solution to the problem }\end{array}$ \\
\hline Not relevant/ no reply & $13 \%$ & \\
\hline
\end{tabular}


Analysis of the reasons for the students' choices indicated that some of the reasons related to the technical aspect of computer use in contrast to submission in hardcopy. It seems that the choice depends on the student's learning style and which method feels more comfortable for the student when coping with assignments - either hardcopy, which should receive detailed personal feedback from the teaching assistant, or through the OAC, which provides immediate feedback which only relates to the final results.

\section{Discussion and Conclusions}

This study examined students' attitudes in an introductory engineering course, relating to six dimensions concerning the submission of online assignments. The research findings indicate possible directions for the improvement of the use of the WA:

1. Despite the submission of weekly assignments through the WA, students only expressed a neutral attitude toward its contribution to their understanding of the studied material. A possible important reason is the fact that in many cases the WA only checks the final solution but not the way in which the question was solved. Other studies indicate that it is desirable to add components to the OAC, which can help students with the path to the solution as well, for example: hints, structured exercises, exercises including conceptual understanding.

2. The OAC contributes to the lecturers' consideration of students' difficulties during the course. This attitude is explained due to the tools that the WA provides, helping the lecturer to identify difficulties and to react to them in real-time.

3. Students feel that online submission helps them to succeed in the course. This finding can be explained in several ways:

a. The students were asked many questions every week through the WA at different levels of difficulty and with different representations. This exposes them to different aspects of the studied subjects.

b. Submission of online assignments is awarded a weight of $10 \%$ in the final grade for the course. This component usually contributes to the improvement of the final course grade.

4. In contrast to previous findings concerning the students' tendency to cheat when presenting assignments online, in this study most students actually indicated that they did not try to cheat when using the WA. This finding should be investigated further.

5. There was no significant finding regarding which method of exercises was preferred by the students either in the statistical analysis or in the content analysis. It was found that $39 \%$ preferred to submit their assignment in hardcopy, while $37 \%$ preferred to present assignments online or with mixed methods.

Despite the limitation of this study due to the fact that it was limited to a single college, the findings of this study as well as previous similar studies (Beichner , 2006) may help lecturers to consider integrating online submission and checking of assignments in introductory academic courses.

\section{References}

Adams, W. K., Perkins, K. K., Podolefsky, N. S., Dubson, M., Finkelstein, N. D., \& Wieman, C. E. (2006). New instrument for measuring student beliefs about physics and learning physics: The Colorado Learning Attitudes about Science Survey. Physical Review Special Topics - Physics Education Research, 2, (1). Retrieved from http://prst-per.aps.org/abstract/PRSTPER/v2/i1/e010101 
Beichner, R. J. (2006). Instructional technology research and development in a U.S. physics education group. European Journal of Engineering Education 31(4), 383-393.

Bonham, S., Beichner, R. J., \& Deardorff, D. (2001). Online homework: Does it make a difference? The Physics Teacher, 39(5), 293-296.

Brewer, D. S. (2009). The effects of online homework on achievement and self-efficacy of college algebra students. Utah State University. Retrieved from: http://digitalcommons.usu.edu/etd/407

Cuadros, J., Yaron, D., \& Leinhardt, G. (2007). "One firm spot": The role of homework as lever in acquiring conceptual and performance competence in college chemistry. Journal of Chemical Education 84(6),1047-1052.

Freasier, B., Collins, G., \& Newitt, P. (2003). A web-based interactive homework quiz and tutorial package to motivate undergraduate chemistry students and improve learning. Journal of Chemical Education, 80(11), 1344-1347.

Harris, H. (2009). Electronic homework management systems: Reviews of popular systems. Journal of Chemical Education, 86(6), 691.

Grijalva, T., Nowell, C., \& Kerkvliet, J. (2006). Academic honesty and online courses. College Student Journal, 40(1), 180-185.

King, C., Guyette, R., \& Piotrowski, C. (2009). Online exams and cheating: An empirical analysis of business students' views. The Journal of Educators Online, 6(1), 1-11.

Liberatore, M. W. (2011). Improved student achievement using personalized online homework for a course in material and energy balance. Chemical Engineering Education, 45(3), 184-190.

Mazur, E. (1997). Peer instruction. Upper Saddle River, NJ: Prentice-Hall.

Novak, G. M., Patterson, E. T., \& Gavrin, A. D. (2000). Just in time teaching: Blending active learning with web technology. Upper Saddle River, NJ: Prentice-Hall.

Pundak, D., Herscovitz, O., Shacham, M., \& Weizer-Biton, R. (2010). Attitudes of face-to-face and elearning instructors toward 'active learning'. European Journal of Open and Distance Learning. Retrieved from: http://www.eurodl.org/? $\mathrm{p}=$ current\&article $=412$

Pundak, D., Maharshak, A., \& Rozner, S. (2004). Successful pedagogy with Web Assignments Checker. Journal of Educational Technology Systems, 33(1), 67-80.

Pundak, D., \& Rosner, S. (2004). Computerized exercising in academic courses. Al Hagova - Magazine for Teaching in Higher Education, 3, 52-56. [Hebrew]

Pundak, D., Herscovitz, O., Shacham, M., \& Weizer-Biton, R. (2010). Attitudes of Face-to-Face and eLearning Instructors toward 'Active Learning'. European Journal of Open and Distance Learning. Retrieved from: $\mathrm{http} / / \mathrm{www}$.eurodl.org/?p=current\&article $=412$

Redish, E. F., Steinberg, R. N., \& Saul, J. M. (1998). Student expectations in introductory physics. American Journal of Physics, 66, 212-224.

Richards-Babb, M., Drelick, J., Henry, Z., \& Robertson-Honecker, J. (2011). Online homework, help or hindrance: What students think and how they perform. Journal of College Science Teaching, 40(4), 8193.

Shkedi, A. (2011). The meaning behind the words - Methodologies of qualitative research: Theory and practice. Tel Aviv: Ramot. (Hebrew).

Watson, G., \& Sotille, J. (2010). Cheating in the digital age: Do students cheat more in online courses? Online Journal of Distance Learning Administration, XIII, I. 


\section{Appendix: Attitudes Questionnaire concerning Online Assignment Checking}

Below you will find 26 statements that may or may not fit your understandings concerning the integration of an Online Assignment Checker (OAC) in this course. You are asked to grade each statement with a circle around a number between 1 and 5. The meaning of these grades appears in the following scale:

\begin{tabular}{|c|c|c|c|c|c|}
\hline 1 & 2 & 3 & 4 & 5 & 0 \\
\hline $\begin{array}{r}\text { completely } \\
\text { disagree }\end{array}$ & disagree & Neutral & Agree & $\begin{array}{r}\text { Completely } \\
\text { agree }\end{array}$ & Irrelevant \\
\hline
\end{tabular}

Please relate to each statement by marking the number next to the statement that most closely expresses your feeling. If you do not understand one of the statements or it is irrelevant, choose 0 . If you understand the statement but you have no clear opinion, choose 3 .

OAC means Online Assignment Checker

\begin{tabular}{|c|c|c|c|c|c|c|c|}
\hline & Statement & \multicolumn{6}{|c|}{ Attitude } \\
\hline 1 & $\begin{array}{l}\text { Practicing with the OAC imposes a heavy learning burden on the } \\
\text { student in comparison with practice in other courses with no OAC. }\end{array}$ & & 1 & 23 & 3 & 4 & 5 \\
\hline 2 & $\begin{array}{l}\text { I think it is important to answer all the questions on the OAC by } \\
\text { myself to gain a better understanding of the subject matter. }\end{array}$ & 0 & 1 & 23 & 3 & 4 & 5 \\
\hline 3 & Because I practice with OAC I find the lectures more interesting & 0 & 1 & 23 & 3 & 4 & 5 \\
\hline 4 & I prefer to submit assignments in writing on using the OAC. & 0 & 1 & 23 & 3 & 4 & 5 \\
\hline 5 & $\begin{array}{l}\text { The lecturer thinks the exercises are important during the course } \\
\text { and relates to the difficulties that arise. }\end{array}$ & 0 & 1 & 2 & 3 & 4 & 5 \\
\hline 6 & $\begin{array}{l}\text { My chances of succeeding in the course improve because of the } \\
\text { consistent exercises on the OAC. }\end{array}$ & 0 & 1 & 2 & 3 & 4 & 5 \\
\hline 7 & $\begin{array}{l}\text { Practicing with OAC during the course do not help me to under- } \\
\text { stand the scientific terms learned in the course }\end{array}$ & 0 & 1 & 2 & 3 & 4 & 5 \\
\hline 8 & $\begin{array}{l}\text { Practicing with OAC give me a better preparation for the lesson in } \\
\text { comparison to courses that have no online practice. }\end{array}$ & 0 & 1 & 2 & 3 & 4 & 5 \\
\hline 9 & $\begin{array}{l}\text { I sometimes use my friends' homework without having answered } \\
\text { the homework questions in the OAC by myself. }\end{array}$ & 0 & 1 & 23 & 3 & 4 & 5 \\
\hline 10 & $\begin{array}{l}\text { My involvement in the course has not increased as a result of my } \\
\text { practice the OAC. }\end{array}$ & 0 & 1 & 2 & 3 & 4 & \\
\hline 11 & $\begin{array}{l}\text { My achievements in the course did not improve after I submitted } \\
\text { the assignments through the OAC. }\end{array}$ & 0 & 1 & 2 & 3 & 4 & \\
\hline 12 & $\begin{array}{l}\text { Submission of assignments through the OAC is the most appropri- } \\
\text { ate method for students in the } 21 \text { st century, in comparison to sub- } \\
\text { mission in hard copy. }\end{array}$ & & 1 & 2 & 3 & 4 & \\
\hline
\end{tabular}




\begin{tabular}{|c|c|c|c|c|c|c|c|}
\hline & Statement & \multicolumn{6}{|c|}{ Attitude } \\
\hline 13 & $\begin{array}{l}\text { Feedback given by OAC is methodical and effective in comparison } \\
\text { to feedback given in other courses. }\end{array}$ & & 12 & 23 & 3 & 4 & 5 \\
\hline 14 & $\begin{array}{l}\text { The opportunity given to correct mistakes when submitting assign- } \\
\text { ments in a course through the OAC helps me to gain a better under- } \\
\text { standing in the course. }\end{array}$ & 0 & 12 & 23 & 3 & 4 & 5 \\
\hline 15 & $\begin{array}{l}\text { It's possible to guess the correct answers in OAC even without solv- } \\
\text { ing the assignment questions. }\end{array}$ & 0 & 12 & 23 & 3 & 4 & 5 \\
\hline 16 & $\begin{array}{l}\text { The immediate feedback given by the OAC encourages me to per- } \\
\text { form the assignments. }\end{array}$ & 0 & 12 & 23 & 3 & 4 & 5 \\
\hline 17 & $\begin{array}{l}\text { Because I practice with the OAC I can apply in a better way the sci- } \\
\text { entific information learned in the course. }\end{array}$ & 0 & 12 & 23 & 3 & 4 & 5 \\
\hline 18 & $\begin{array}{l}\text { Work with the online assignments does not arouse my curiosity to } \\
\text { go deeper into the scientific phenomena studied in the course. }\end{array}$ & 0 & 12 & 23 & 3 & 4 & 5 \\
\hline 19 & $\begin{array}{l}\text { Succeeding in the course is important for my professional develop- } \\
\text { ment, so that I think it is important to learn to answer the assign- } \\
\text { ments by myself. }\end{array}$ & 0 & 12 & 23 & 3 & 4 & 5 \\
\hline 20 & $\begin{array}{l}\text { It's impossible to succeed in a course when you get the correct an- } \\
\text { swers from friends, without reading and solving the questions that } \\
\text { appear in the OAC. }\end{array}$ & 0 & 11 & 23 & 3 & 4 & 5 \\
\hline 21 & $\begin{array}{l}\text { During the lecture the lecturer does not spend time on the subjects } \\
\text { that appeared in the OAC. }\end{array}$ & 0 & 12 & 23 & 3 & 4 & 5 \\
\hline 22 & $\begin{array}{l}\text { The questions asked in the OAC help me to understand the subject } \\
\text { matter discussed in the course. }\end{array}$ & 0 & 12 & 23 & 3 & 4 & 5 \\
\hline 23 & $\begin{array}{l}\text { During the lectures or the tutorials in the course there is sometimes } \\
\text { discussions about the difficulties arose from practicing in the OAC. }\end{array}$ & 0 & 12 & 23 & 3 & 4 & 5 \\
\hline 24 & $\begin{array}{l}\text { As a result of the online practice I am more willing to learn topics } \\
\text { associated with the course. }\end{array}$ & 0 & 12 & 23 & 3 & 4 & 5 \\
\hline 25 & $\begin{array}{l}\text { The questions that appear in the OAC encourage higher order think- } \\
\text { ing no less than questions given regular homework in other courses. }\end{array}$ & 0 & 1 & 23 & 3 & 4 & \\
\hline 26 & $\begin{array}{l}\text { The assignments presented on the OAC fits the subject matter stud- } \\
\text { ied in the course. }\end{array}$ & 0 & 1 & 23 & 3 & 4 & \\
\hline 27 & $\begin{array}{l}\text { Sometimes when I am temporarily stressed, I tend to get my friends' } \\
\text { homework, without solving the OAC questions by myself. }\end{array}$ & 0 & 1 & 23 & 3 & 4 & \\
\hline 28 & $\begin{array}{l}\text { Usually I solve the questions completely and then submit the final } \\
\text { solution through the OAC }\end{array}$ & 0 & 1 & 23 & 3 & 4 & \\
\hline
\end{tabular}

\section{Open Questions}

29. Until now, in how many courses have you studied with the assistance of the OAC?

30. If you are given the choice to submit homework through OAC or through hard copy - what would you prefer? Explain your choice. 


\section{Biographies}

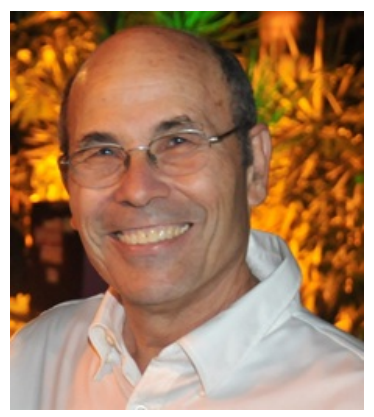

Dr. David Pundak - Senior Lecturer in Physics and faculty in Kinneret College and Head of E-Learning Unit in ORT Braude College (OBC). For the past twenty years he has been involved in research and development in science and physics education. Having set the goal to advance science education,. Dr. Pundak founded the center for science education - "Blossoms of Science" at the Kinneret College. The center integrated research done by scientists with enquiry projects conducted by juniorhigh and high schools students. At OBC Dr. Pundak founded and heads the E-Learning Unit which focuses on the development of courses learned through the Internet. The developed web sites enable students and instructors to take advantage of web technology and to enrich the social activities and the knowledge resources of the courses. At the same time, he studies the influence of Web technology on instruction and learning. Instructors' Attitudes toward Active Learning.

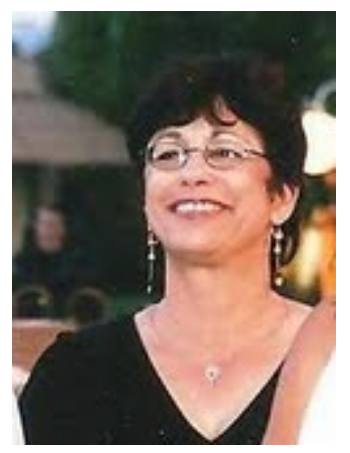

Dr. Miri Shacham works as a lecturer and researcher in the Teaching Department and in the Centre for Teaching and Learning of Ort Braude Academic College in Israel. She also works as a researcher in the field of Stress and Trauma in the Community Stress Prevention Centre of Tel Hai College in Israel. She is working in The Israeli Ministry of Education as an Organizational Counselor for school principals. She was a member of an English-Israeli Team that developed a special international PhD Program in Anglia Ruskin University in the UK. Her major researches and publications are in these areas: Innovation in Science and Technology Education, Learning and Teaching in Higher Education, the influence of and Resilience in war times.

Web technology on instruction and learning, Doctoral Education, Trauma

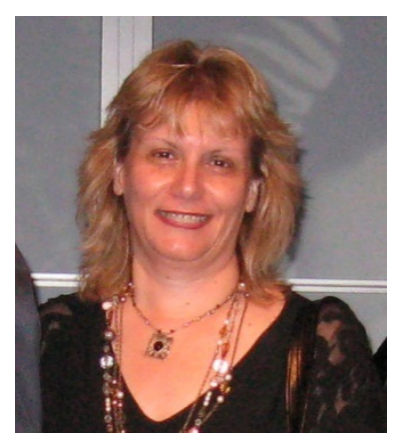

Dr. Orit Herscovitz is a Senior Researcher and Lecturer of graduate and undergraduate courses and advisor of graduate students in the Department of Education in Technology and Science, at the Technion, Israel Institute of Technology. She is also the director of the Israeli National Center for "Science for All" teachers. Her activities during the last 15 years at the Technion include developing and assessing casebased science curricula and promoting professional development of pre- and in-service science and technology teachers. In these two research fields she has been promoting the enhancement of constructivist learning environments via advanced educational technologies. Her publications include articles and book chapters in science education and educational technology. She has also written four learning units for high school students as first author together with colleagues. 